\title{
Determination of Paracetamol at a Graphite-Polyurethane Composite Electrode as an Amperometric Flow Detector
}

\author{
Priscila Cervini and Éder Tadeu Gomes Cavalheiro*
}

Instituto de Química de São Carlos, Departamento de Química e Física Molecular, Universidade de São Paulo, Av. Trabalhador São-carlense, 400, 13566-390 São Carlos-SP, Brazil

\begin{abstract}
Um eletrodo compósito de grafite-poliuretana sem modificação foi avaliado como um detector amperométrico para análise em fluxo, na determinação de paracetamol (APAP) em formulações farmacêuticas. Uma curva analítica foi obtida com região linear entre 5,00 x $10^{-5} \mathrm{e} 5,00 \times 10^{-3} \mathrm{~mol} \mathrm{~L}^{-1}$, com um limite de detecção de $18,9 \mu \mathrm{mol} \mathrm{L}^{-1}$ e 180 determinações por hora, depois de parâmetros otimizados como potencial de detecção, volume de amostragem, e vazão da solução carregadora. Interferência de ácido ascórbico foi observada, entretanto foi possível contorná-la, como visto pelos resultados que concordaram com HPLC com nível de confiança de 95\%. Estes resultados mostraram que o compósito grafite-poliuretana pode ser usado como um detector amperométrico para análise em fluxo na determinação de APAP.
\end{abstract}

A bare graphite-polyurethane composite was evaluated as an amperometric flow injection detector in the determination of paracetamol (APAP) in pharmaceutical formulations. A linear analytical curve was observed in the $5.00 \times 10^{-5}$ to $5.00 \times 10^{-3} \mathrm{~mol} \mathrm{~L}^{-1}$ range with a minimum detectable net concentration of $18.9 \mu \mathrm{mol} \mathrm{L}^{-1}$ and 180 determinations $\mathrm{h}^{-1}$, after optimization of parameters such as the detection potential, sample loop volume, and carrier solution flow rate. Interference of ascorbic acid was observed, however, it was possible overcome the interference, reaching results that agreed with HPLC within 95\% confidence level. These results showed that the graphite-polyurethane composite can be used as an amperometric detector for flow analysis in the determination of APAP.

Keywords: paracetamol, graphite-PU composite electrode, FIA

\section{Introduction}

Paracetamol (N-acetyl-p-aminophenol, acetaminophen, APAP) had been used for a long time and is one of the most extensively employed drugs in the world. It was first used in medicine by von Mering in 1893. However, it was first discovered to have both analgesic and antipyretic properties in the late 19th century. APAP is the active ingredient of several pharmaceutical products, in different dosage forms and doses, alone or in association. It is a suitable alternative for the patients who are sensitive to aspirin and safe up to therapeutic doses. ${ }^{1}$

It has low toxicity when used at the recommended doses. ${ }^{2}$ Nevertheless, the ease with which the general public can access this drug makes it frequently associated with overdoses, in this situation causing serious or even fatal hepatic damage. ${ }^{3}$ The treatment of a supposed overdose

*e-mail: cavalheiro@iqsc.usp.br of APAP demands a rapid and reliable determination of its concentration in blood serum. So, APAP and its metabolites have been extensively investigated. ${ }^{4}$

Several analytical techniques such as titrimetry, ${ }^{5}$ spectrophotometry, ${ }^{6,7}$ spectrofluorometry, ${ }^{8}$ colorimetry, ${ }^{9}$ HPLC, ${ }^{10,11}$ and many other methods are proposed for the determination of APAP. Electrochemical methods, especially the voltammetric and amperometric ones gave the opportunity to study the oxidation mechanisms. The cyclic voltammetric study concerning the electrochemical oxidation of APAP was described in the work of Kissinger et al..$^{2}$

Since voltammetric techniques are more selective, less costly and less time-consuming, they are widely used for the determination of APAP in pharmaceutical formulations and body fluids. Voltammetric determinations of APAP at chemically modified electrodes, ${ }^{13}$ glassy carbon electrode,,${ }^{14}$ platinum electrode, ${ }^{15}$ and at other electrodes ${ }^{16}$ have been described. 
On the other hand, flow injection analysis (FIA) has been used routinely since its inception to provide sample handling automated control. ${ }^{17}$ FIA involves the injection of a reproducible sample volume into a continuous flowing unsegmented carrier solution, followed by quantification at a detector device. In addition to automated control, FIA offers other advantages. These include convective mass transport, matrix exchange, and increased precision. The combination of FIA with electrochemical detection is attractive because of the flexibility of the former and the diagnostic power of the latter. ${ }^{18,19}$

In order to join the advantages of both FIA and voltammetric techniques, an electrode suitable to use under hydrodynamic conditions is necessary. We have recently proposed the use of a graphite-polyurethane composite as an electrode material that is inexpensive, long life, easy to prepare, and that can be used over a wide range of potentials and $\mathrm{pH}$. We also found that for non-adsorbent analytes the electrode did not require frequent surface renewing and operates as an amperometric sensor in flow systems. ${ }^{20-22}$

Recently an extensive review on methods for determination of APAP was presented by Espinosa and coworkers. ${ }^{23}$ In that paper is possible to note that although flow injection procedures with spectrophotometric detection and several electroanalytical methods have been described for APAP detection, few works on direct determination in an amperometric flow injection system is described. An other remarkable fact is that with the graphite polyurethane composite electrode the detection potential can be lowered down to 0.5 (vs. $\mathrm{Ag} / \mathrm{AgCl}$ ).

This work describes the optimization of a flow injection system with electrochemical detection for the determination of APAP in pharmaceutical formulations, using a $60 \%$ $(\mathrm{m} / \mathrm{m})$ graphite-polyurethane (PU) composite electrode as an amperometric detector in a flow injection procedure.

\section{Experimental}

\section{Apparatus}

All the reference or sample solutions were injected manually into the carrier stream using a laboratoryconstructed three-piece injector-commutador made of polymethylmethacrylate (PMMA), ${ }^{24}$ with two fixed side bars and a sliding central bar, which is moved for sampling and injection. The solutions were conducted with polyethylene tubing $(0.8 \mathrm{~mm}$ i.d, Fiotubos, Brazil) and propelled with an IPC 8-channel peristaltic (Ismatec, Swtizerland) pump. An illustration of such system is presented in Figure 1.

Potentials were measured with an AUTOLAB PGSTAT-30 (Ecochemie, The Netherlands) potentiostat/

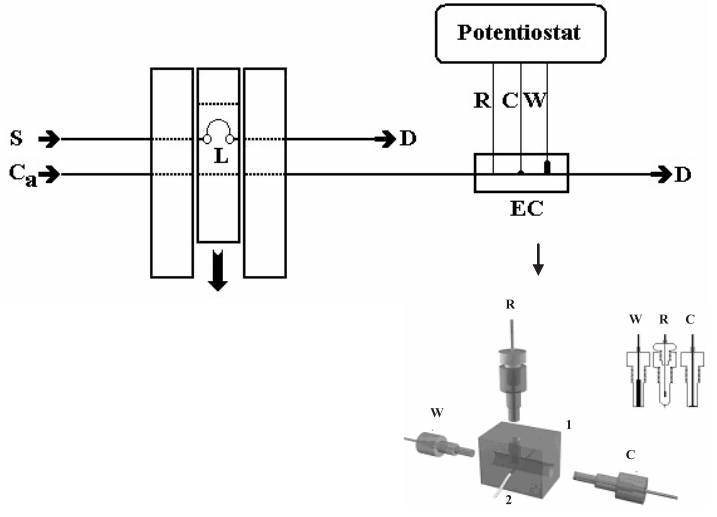

Figure 1. Scheme of the flow injection system with electrochemical detection used for the determination of APAP: $\mathbf{S}$ : sample, $5.00 \times 10^{-3} \mathrm{~mol}$ $\mathrm{L}^{-1}$ APAP solution; Ca: carrier, universal buffer $\mathrm{pH}$ 8.0; $\mathbf{D}$, waste; $\mathbf{L}$, loop; $\mathbf{R}, \mathbf{W}, \mathbf{C}$, reference $(\mathrm{Ag} / \mathrm{AgCl})$, working $(60 \%$, graphite, $\mathrm{m} / \mathrm{m})$ and counter (platinum disk) electrodes, respectively; EC, electrochemical flow-through cell; Potentiostat, Autolab PGSTAT-30 potenciostate-galvanostate. In the detail a scheme of the EC used in the measurements in FIA system (1) Block of polyurethane resin, (2) polyethylene tube.

galvanostat coupled to a personal computer and controlled with a GPES 4.9 software. The measurements were performed in a three-electrode configuration flow cell (details in Figure 1) using the graphite-PU composite electrode $60 \%$ (graphite, $\mathrm{m} / \mathrm{m}$ ) or a glassy carbon (GC) as working electrodes. $\mathrm{An} \mathrm{Ag} / \mathrm{AgCl}, \mathrm{KCl} 0.1 \mathrm{~mol} \mathrm{~L}^{-1}$ was used as reference and a platinum disk $(\varnothing=3 \mathrm{~mm})$ was a counter electrode.

The body of the electrochemical flow cell (details in Figure 1) was fabricated with an unmodified castor oil polyurethane resin (Poliquil, Brazil) with an effective volume of $25 \mu \mathrm{L}^{20}$

\section{Reagents and solutions}

Solutions were prepared with twice distilled water in a quartz stiller. The APAP used was of analytical reagent grade (Natural Pharma, Brazil). Stock $5.00 \mathrm{mmol} \mathrm{L}^{-1}$ APAP in universal buffer $\mathrm{pH} 8$ solution was freshly prepared and adequately diluted in order to obtain the working solutions. The pharmaceutical samples were Tylenol (Janssen-Cilag Farmacêutica LTDA, Brazil), Resfenol (Kley Hertz S.A., Brazil), Buscopan Plus (Boehringer Ingelheim, Brazil) and Trimedal (Novartis Biociências S.A., Brazil).

\section{Procedures for pharmaceutical formulation analysis}

According to the Brazilian Pharmacopea recommendations, ${ }^{25}$ twenty tablets were weighed and powdered. Accurately weighed portions of powder equivalents to 750, 500 and $500 \mathrm{mg}$ for Tylenol, Buscopan 
Plus and Trimedal, respectively, and $40 \mathrm{mg}$ of Resfenol solution were dissolved in $25 \mathrm{~mL}$ of universal buffer $\mathrm{pH} 8$ to obtain solutions correspondent to $2.00 \times 10^{-3} \mathrm{~mol} \mathrm{~L}^{-1}$ in APAP. The solutions were sonicated for 10 minutes to complete the dissolution.

\section{Procedures for working electrode}

The composite $60 \%$ (graphite, $\mathrm{m} / \mathrm{m}$ ) electrode was prepared as previously described. ${ }^{20}$ Briefly, adequate amounts of the polyol and hardener, in proportion of 0.8 to 1 according to the manufacturer recommendation, and graphite (Aldrich, USA) were mixed in a mortar for $5 \mathrm{~min}$ in order to obtain a mixture with $60 \%$ of graphite $(\mathrm{m} / \mathrm{m})$. The resulting mixture is inserted in a manual press and extruded as $3.0 \mathrm{~mm}$ diameter rods, with geometrical area $0.0707 \mathrm{~cm}^{2}$. The composite was cured for $24 \mathrm{~h}$ at room temperature and cutted in pieces with $1.0 \mathrm{~cm}$ long. A copper wire $(\phi 1.0 \mathrm{~mm})$ was attached to these rods with the help of a silver epoxy (EPO-TEK 410E, Epoxy Technology, USA), conducting resin in order to reach electric contact. This set was then inserted in an electrode body built up in PU resin, $5.0 \mathrm{~mm}$ i.d. (detail Figure 1) and sealed with the PU resin. A curing time of $24 \mathrm{~h}$ was adopted before use. Surface renewal was not necessary during the experiments as no APAP adsorption on the electrode surface was observed.

\section{Flow injection measurements}

The effect of different parameters relative to the flow system, such as carrier solution flow rate $(1.4,2.6,3.9,5.2$, 6.5 and $\left.7.7 \mathrm{~mL} \mathrm{~min}^{-1}\right)$, detection potential (400, 450, 500, 550 and $600 \mathrm{mV}$ vs. $\mathrm{Ag} / \mathrm{AgCl}$ ) and sample loop volume $(25,50,75,100,126$ and $151 \mu \mathrm{L})$ were evaluated.

Before the measurements the composite electrode was placed in the voltammetric cell in contact with the carrier solution, flowing during $2 \mathrm{~min}$. This showed to be enough to obtain a stable baseline.

Using the optimized conditions an analytical curve was obtained by injection of different concentrations of APAP, in increasing order from $5.00 \times 10^{-5}$ to $5.00 \times 10^{-3} \mathrm{~mol} \mathrm{~L}^{-1}$, using the optimized parameters. The same procedure was repeated, but now in decreasing order to check if any memory effect was present. The injections were performed in quintuplicate, only for the standard solutions.

In the determination of APAP in pharmaceutical formulations, each standard APAP solution was injected three times in the increasing order from $5.00 \times 10^{-5}$ to $3.00 \times 10^{-3} \mathrm{~mol} \mathrm{~L}^{-1}$, after that, four samples of $2.00 \times 10^{-3} \mathrm{~mol} \mathrm{~L}^{-1}$ APAP content in pharmaceutical formulations (Tylenol, Resfenol, Buscopan Plus and Trimedal) were injected three times. Then, the same procedure was repeated, but now in decreasing order, for the standard solutions only.

\section{Comparison method}

The comparison method was realized according to the American Pharmacopea recommendations. ${ }^{26}$ Liquid chromatography (HPLC) were recorded in a Shimadzu SCL-10A VP chromatograph, equipped with a RP-18 column $(150 \times 4.6 \mathrm{~mm}, 5 \mu \mathrm{m}$, Aldrich, USA). The detector used was an UV vis SPD-10A VP (Shimadzu, USA).

\section{Results and Discussion}

\section{Flow injection parameters}

The following parameter were optimized: the flow rate, a hydrodynamic factor which plays an important role in the efficiency of mass transport of analyte from bulk solution toward the electrode surface, being a major factor affecting the magnitude of peak currents in flow injection amperometry; the detection potential, which plays an important role in the selectivity and sensitivity of the analysis and the sample volume that defines the amount of analyte to be detected.

The effect of the flow rate on the peak current was evaluated between 1.4 and $7.7 \mathrm{~mL} \mathrm{~min}^{-1}$ by successive injections of $5.00 \times 10^{-3} \mathrm{~mol} \mathrm{~L}^{-1}$ APAP solution in universal buffer, $\mathrm{pH} 8$ in which better sensitivity and peak resolution have been observed previously. The current increased continuously over the all range of flow rates investigated. Then $6.5 \mathrm{~mL} \mathrm{~min}^{-1}$ was chosen for further studies, since above this flow rate the increase in the current signal is not enough to justify the reagent consumption and waste generation. Additionally, for higher flow rates, the standard deviation is higher.

The effect of the detection potential was evaluated between 400 and $600 \mathrm{mV}$ by successive injection of $5.00 \times 10^{-3} \mathrm{~mol} \mathrm{~L}^{-1}$ APAP solution. These values were chosen because in cyclic voltammetric the oxidation peak of APAP occurs in approximately $400 \mathrm{mV}$ (Figure 2.a). The effect of the detection potential showed that there is no difference in the currents obtained at potential values higher than $500 \mathrm{mV}$, remaining practically constant (Figure 2.b). Thus, $500 \mathrm{mV}$ was chosen for further studies since it presented less standard deviation between successive measurements and lower risk of oxidizing other species.

The effect of the sample volume in the transient signals was investigated for volumes from 25 to $151 \mu \mathrm{L}$ using a 

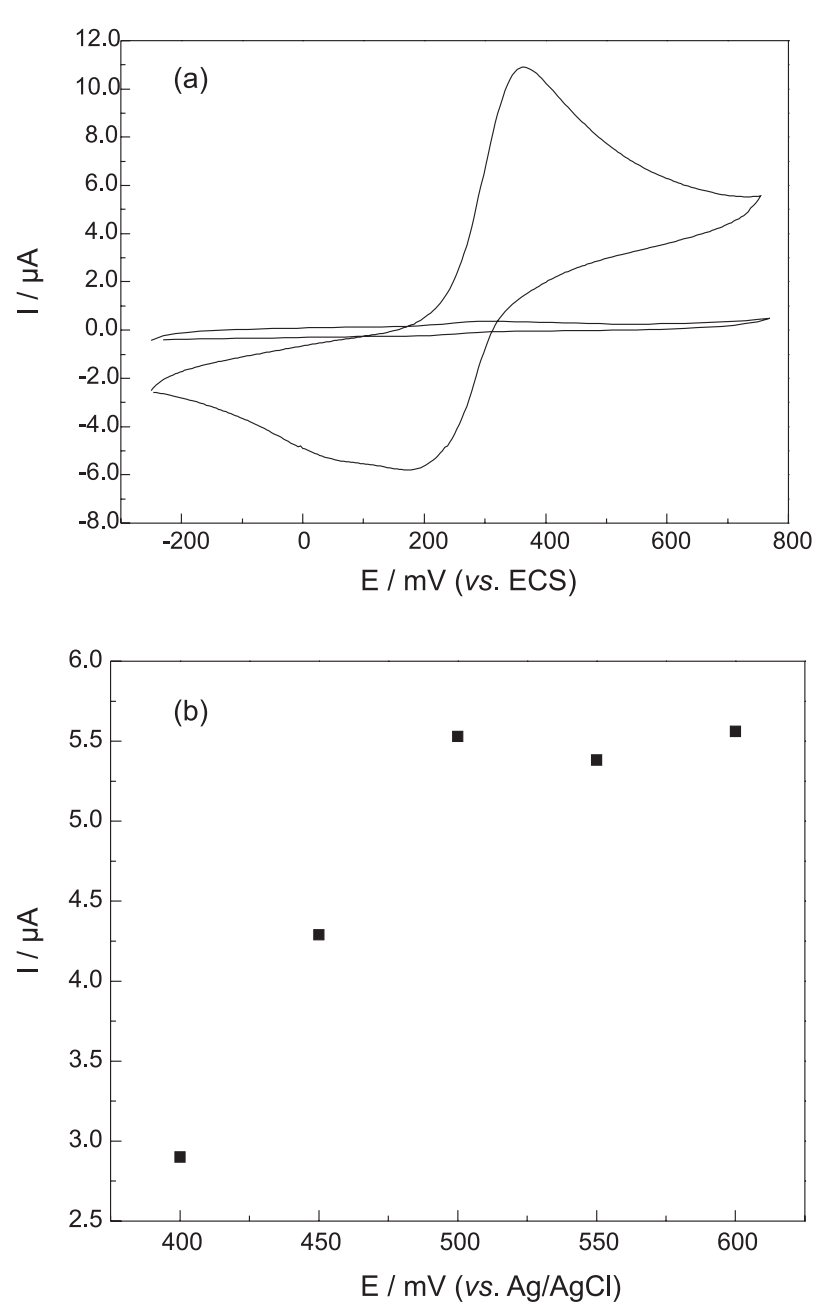

Figure 2. (a) Ciclic voltammogram of $1.00 \times 10^{-3} \mathrm{~mol} \mathrm{~L}^{-1} \mathrm{APAP}$ solution using $60 \%$ (graphite, $\mathrm{m} / \mathrm{m}$ ) composite electrode in universal buffer $\mathrm{pH} 8$, $\mathrm{v}=25 \mathrm{mV} \mathrm{s}^{-1}$. (b) Effect of the detection potential in the amperometric response of a $1.00 \times 10^{-3} \mathrm{~mol} \mathrm{~L}^{-1}$ APAP solution in the FIA system using an universal buffer solution $\mathrm{pH} 8.0$ as carrier, $3.9 \mathrm{~mL} \mathrm{~min}^{-1}$ flow rate, $50 \mu \mathrm{L}$ sample loop, at the $60 \%$ (graphite, $\mathrm{m} / \mathrm{m}$ ) composite as working electrode.

$5.00 \times 10^{-3} \mathrm{~mol} \mathrm{~L}^{-1}$ APAP solution, under a flow rate of $6.5 \mathrm{~L} \mathrm{~min}^{-1}$ and detection potential fixed at $500 \mathrm{mV}$. The current signal increased significantly up to $100 \mu \mathrm{L}$. For higher sample loop volumes the signal remained practically constant. So, this volume was selected.

\section{Analytical curve}

The analytical curve (Figure 3) was obtained in order to evaluate the behavior of the amperometric response of the composite $60 \%$ (graphite, $\mathrm{m} / \mathrm{m}$ ) in comparison to the concentration of APAP.

Using the optimized conditions, a linear response was obtained in the $5.00 \times 10^{-5}$ to $5.00 \times 10^{-3} \mathrm{~mol} \mathrm{~L}^{-1}$ APAP concentration range (Figure 3 ). The observed

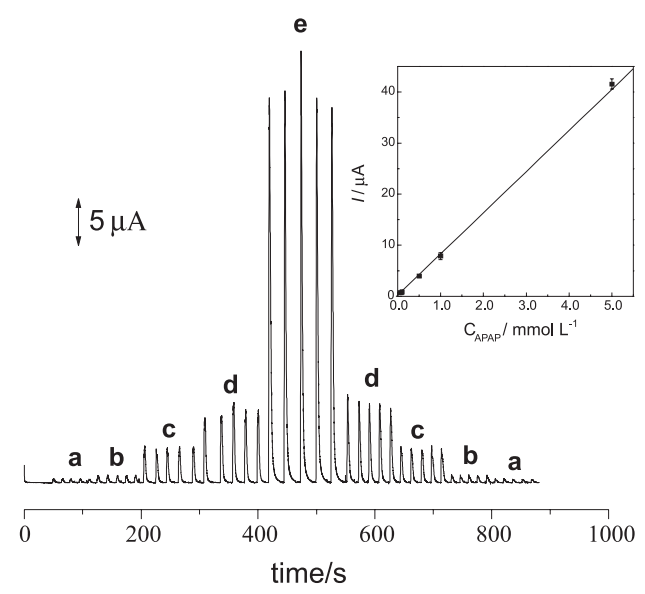

Figure 3. Transient signals obtained at the composite $60 \%$ (graphite, $\mathrm{m} / \mathrm{m}$ ) electrode using (a) $5.00 \times 10^{-5}$, (b) $1.00 \times 10^{-4}$, (c) $5.00 \times 10^{-4}$, (d) $1.00 \times 10^{-3}$ and (e) $5.00 \times 10^{-3} \mathrm{~mol} \mathrm{~L}^{-1}$ of APAP and universal buffer $\mathrm{pH} 8$ as a carrier, flow rate of de $6.5 \mathrm{~mL} \mathrm{~min}^{-1}$, detection potential of $500 \mathrm{mV}$ (vs. $\mathrm{Ag} / \mathrm{AgCl}$ ) and sample loop volume of $100 \mu \mathrm{L}$. In the detail the linear portion of the analytical curve.

linear region in all the analyzed range, follows the linear equation 1.

$\mathrm{y}=-0.35 \mu \mathrm{A}+8.8 \mathrm{~mA} \mathrm{mmol}^{-1} \mathrm{~L} \mathrm{C}_{\mathrm{APAP}}$,

$(\mathrm{n}=5, \mathrm{R}=0.999)$

Analytical frequencies of 180 determinations per hour were observed under the optimized conditions. The limit of detection (LOD) obtained in this interval was of $18.9 \mu \mathrm{mol} \mathrm{L} \mathrm{L}^{-1}$, determined as three times the standard deviation of the blank $\left(\mathrm{S}_{\mathrm{d}}\right)$ divided by the angular coefficient of straight line $(b)^{27}$

$\mathrm{LOD}=3 \mathrm{~S}_{\mathrm{d}} / \mathrm{b}$

The LOD for APAP at a glassy carbon electrode with a geometrical area of $0.196 \mathrm{~cm}^{2}$, used as amperometric flow detector under the same experimental conditions for comparison was $108 \mu \mathrm{mol} \mathrm{L}^{-1}$, i.e. six times higher, and it presented saturation at the electrode surface for concentrations values higher than $1.00 \times 10^{-3} \mathrm{~mol} \mathrm{~L}^{-1}$.

A peak current of $32.1 \pm 0.1 \mu \mathrm{A}$ for 10 successive injections of a $5.00 \times 10^{-3} \mathrm{~mol} \mathrm{~L}^{-1}$ APAP solutions under the optimized conditions were observed, a variance coefficient of $0.3 \%$.

\section{Determination of APAP in pharmaceutical formulations}

The applicability of the composite electrode $60 \%$ (graphite, $\mathrm{m} / \mathrm{m}$ ) as a FIA amperometric detector for the determination of APAP was verified analyzing four pharmaceutical formulations as described previously. 
Table 1. Determination of APAP in pharmaceutical formulations using both the proposed FIA procedure at the $60 \%$ (graphite, $m / m$ ) composite electrode and HPLC one

\begin{tabular}{|c|c|c|c|c|c|}
\hline \multirow{2}{*}{ Sample } & \multicolumn{3}{|c|}{ Paracetamol (mg /tablet) } & \multirow{2}{*}{$\mathrm{E}_{1} \%$} & \multirow[t]{2}{*}{$\mathrm{E}_{2} \%$} \\
\hline & Labeled & FIA $^{a}$ & HPLC $^{b}$ & & \\
\hline Tylenol & 750 & $748 \pm 1$ & $747 \pm 1$ & +0.07 & -0.27 \\
\hline Resfenol $^{\mathrm{c}}$ & 40.0 & $40.6 \pm 0.2$ & $39.8 \pm 0.1$ & +2.01 & +1.50 \\
\hline Buscopan Plus & 500 & $514 \pm 1$ & $498 \pm 1$ & +3.15 & +2.80 \\
\hline Trimedal & 500 & $482 \pm 1$ & $499 \pm 1$ & -3.33 & -3.60 \\
\hline
\end{tabular}

${ }^{\mathrm{a}}$ result \pm standard deviation $(\mathrm{n}=3)$; ${ }^{\mathrm{b}} 2$ determination; ${ }^{\mathrm{c}} 40 \mathrm{mg} / 100 \mathrm{~mL}$ of solution; $\mathrm{E}_{1}$ : FIA $v s$. HPLC (FIA-HPLC/HPLC) x100\%; E (FIA-labeled/labeled) x $100 \%$

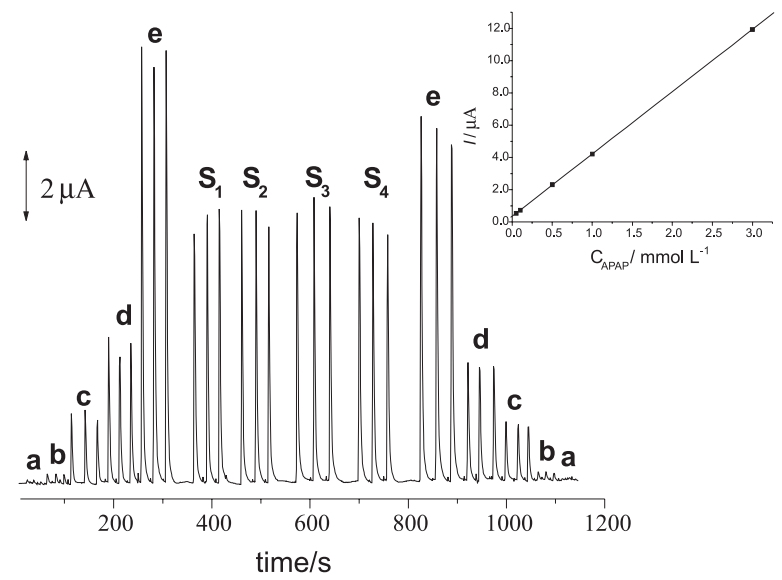

Figure 4. Transient signals for determination of APAP in pharmaceutical formulations using $60 \%$ (graphite, $\mathrm{m} / \mathrm{m}$ ) composite electrode in universal buffer $\mathrm{pH} 8$ as a carrier, flow rate of de $6.5 \mathrm{~mL} \mathrm{~min}^{-1}$, detection potential of $500 \mathrm{mV}$ (vs. $\mathrm{Ag} / \mathrm{AgCl})$ and sample loop volume of $100 \mu \mathrm{L}$, at (a) 5.00 $\times 10^{-5}$, (b) $1.00 \times 10^{-4}$, (c) $5.00 \times 10^{-4}$, (d) $1.00 \times 10^{-3}$, (e) $3.00 \times 10^{-3} \mathrm{~mol}$ $\mathrm{L}^{-1},\left(\mathrm{~S}_{1}\right),\left(\mathrm{S}_{2}\right),\left(\mathrm{S}_{3}\right)$ and $\left(\mathrm{S}_{4}\right)$, referent to Tylenol, Resfenol, Buscopan Plus and Trimedal $2.00 \times 10^{-3} \mathrm{~mol} \mathrm{~L}^{-1}$, respectively. In the detail the linear region of the analytical curve.

Figure 4 shows the transient signals obtained for standard and sample solutions, and the resulting analytical curve.

Table 1 presents the obtained results using the proposed flow procedure and the HPLC as a comparative method. The results agreed within $95 \%$ of confidence level according to the $t$-Student test. ${ }^{28}$

Interference study was carried out in order to investigate the effect of ascorbic acid on the amperometric response of APAP since some commercial formulations can contain both analytes. FIA experiments were carried out for $5.00 \times 10^{-4} \mathrm{~mol} \mathrm{~L}^{-1}$ APAP in presence of different of ascorbic acid concentrations. Interference was represented as an increase of 10, 15 e $14 \%$ in the APAP current, respectively for 2.50, 5.00 and $10.0 \times 10^{-4} \mathrm{~mol} \mathrm{~L}^{-1}$ of ascorbic acid.

One of the formulations analyzed (Trimedal) present both ascorbic acid and APAP. However, it was possible to determine APAP in the presence of AA even in this sample reaching results that agreed with those from chromatography, as observed in Table 1 . This is probably related to the very low concentration of the interferant in the formulation, since the sample contains $500 \mathrm{mg}$ of APAP and only $40 \mathrm{mg}$ of AA.

As any interference was observed by the other components of the pharmaceutical formulations it might be possible that this procedure can be used for APAP quantification.

\section{Conclusions}

According to these results it can be concluded that the composite $60 \%$ (graphite, $\mathrm{m} / \mathrm{m}$ ) electrode represents an interesting alternative to be used in FIA for the determination of APAP with a detection limit in the $\mu \mathrm{mol} \mathrm{L} \mathrm{L}^{-1}$ level without modification. The method has been satisfactorily applied to determination of APAP in pharmaceutical formulations.

Although lower detection limits can be found in the literature, the graphite-PU composite electrode is an inexpensive and long life device that can be used with any further modification.

\section{Acknowledgments}

The authors are indebted to the Brazilian agencies CNPq and FAPESP for PC post-doctoral fellowship, and FAPESP for financial support (05/04297-1).

\section{References}

1. Wade, A. ed. In Martindale, The Extra Pharmacopea, $27^{\text {th }}$ ed., The Pharmaceutical Press: London, 1978.

2. Sweetman, S. C. ed. In Martindale, The Complete Drug Reference, $3^{\text {rd }}$ ed., The Pharmaceutical Press: London, 2002.

3. Anker, A.; Clinical Toxicology, W. B. Saunders Company: Philadelphia, 2001.

4. Miner, D. J.; Rice, J. R..; Riggin, R. M.; Kissinger, P. T; Anal. Chem. 1981, 53, 2258.

5. Kumar, K. G.; Letha, R..; J. Pharm. Biomed. Anal. 1997, 15, 1725. 
6. Canadá, M. J. A.; Reguera, M. I. P.; Medina, A. R.; de Cordova, M. L. F.; Diaz, A. M.; J. Pharm. Biomed. Anal. 2000, 22, 59.

7. Ni, Y.; Liu, C.; Kokot, S.; Anal. Chim. Acta 2000, 419, 185.

8. Vilchez, J. L.; Blanc, R.; Avidad, R.; Navalon, A.; J. Pharm. Biomed. Anal. 1995, 13, 1119.

9. Knochen, M.; Giglio, J.; Reis, B. F.; J. Pharm. Biomed. Anal. 2003, 33, 191 .

10. Ravisankar, S.; Vasudevan, M.; Gandhimathi, M.; Suresh, B.; Talanta 1998, 46, 1577.

11. Al-Obaidy, S. S.; Po, A. L. W.; McKiernan, P. J.; Glasgow, J. F. T.; Millership, J.; J. Pharm. Biomed. Anal. 1995, 13, 1033.

12. Kissinger, P. T.; Roston, D. A.; Van Benschoten, J. J.; Lewis, J. Y.; Heineman, W. R.; J. Chem. Educ. 1983, 60, 772.

13. He, F. Y.; Liu, A. L.; Xia, X. H.; Anal. Bioanal. Chem. 2004, 379, 1062.

14. Sandulescu, R.; Mirel, S.; Oprean, R.; J. Pharm. Biomed. Anal. 2000, 23, 77.

15. Zen, J. M.; Ting, Y. S.; Anal. Chim. Acta. 997, 342, 175.

16. Vieira, I. C.; Lupetti, K. O.; Fatibello-Filho, O.; Quim. Nova 2003, 26, 39.

17. Růžička, J.; Hansen, E. H.; Anal. Chim. Acta 1975, 78, 145.

18. Růžička, J.; Hansen, E. H.; Flow Injection Analysis, John Willey: New York, 1988.

19. Karlberg, B.; Pacey, G. E.; Techniques and Instrumentation in Analytical Chemistry, Flow Injection Analysis: A Practical Guide, Elsevier: New York, 1989.
20. Mendes, R. K.; Claro-Neto, S.; Cavalheiro, E. T. G.; Talanta 2002, 57, 909.

21. Mendes, R. K.; Cervini, P.; Cavalheiro, E. T. G.; Talanta 2006, 68, 708.

22. Cervini, P.; Ramos, L. A.; Cavalheiro, E. T. G.; ACAIJ 2006, 2 , 187.

23. Espinosa Bosch, M.; Ruiz Sánchez, A. J.; Sánchez Rojas, F.; Bosch Ojeda, C.; J. Pharm. Biomed. Anal. 2006, 42, 291.

24. Ramos, L. A.; Prieto, K. R.; Cavalheiro, C. C. S.; Cavalheiro, E. T. G.; J. Chem. Educ. 2005, 82, 1815.

25. Farmacopéia Brasileira, $4^{\text {th }}$ ed., Parte I, Atheneu Editora: São Paulo, 1988.

26. The United States Pharmacopeia National Formulary XXVII, U.S. Pharmacopeia Convention: Rockville, 2004.

27. Long, G. L.; Winefordner, J. D.; Anal. Chem. 1983, 55, $712 \mathrm{~A}$.

28. Harris, D.C.; Análise Química Quantitativa, LTC Editora: Rio de Janeiro, 2001.

Received: July 2, 2007

Web Release Date: March 25, 2008

FAPESP helped in meeting the publication costs of this article. 